\title{
糖尿病患者に発症した壊疽性筋膜炎の一症例
}

\author{
医療法人玄真堂 川嶌整形外科病院 \\ 宮 㠃 健 洋 - 永 芳 郁 文 \\ 川嶌眞人 \\ 医療法人立真堂 かわしまクリニック \\ 田村裕 昭
}

\section{Case Study of a Necrotizing Fasciitis Patient with Diabetes}

\author{
Takehiro Miyazaki, Ikufumi Nagayoshi, and Mahito Kawashima \\ Kawashima Orthopaedic Hospital, \\ Oita, Japan \\ Hiroaki Tamura \\ Kawashima Clinic, Oita, Japan
}

\begin{abstract}
The patient was a 55-year-old female with a 10-year history of diabetes. On July 1, 2004, swelling at the tip of the third digit (left hand) developed, although definite cause is unknown. From July 3, redness and swelling increased and she visited a nearby doctor for examination. Exacerbated symptoms were found and the patient was admitted to our hospital on July 7. Upon hospitalization, with the exception of the finger tip, a dark red color, swelling and pressure point pain were seen. Inflammation and laboratory findings (CRP : 15.1 WBC : 11500) were detected, but bacteria was not found in culture. (After hospitalization) On July 9, the diagnosis of necrotizing fasciitis was uncertain. The patient was immediately treated by hyperbaric oxygen (HBO) therapy and intravenous antibiotics. No symptomic improvement was seen. Debridement and amputation of the third digit were performed. On July 13, an expansion of necrotizing tissue on the dorsal side of the hand was found and additional wide area debridement was peformed. On July 18, pig skin coating (brand name: Aroask) was used and no furter growth of necrosis had been seen. Wound granulation was slow.

As a result, it can be said that wide debridement of necrotizing fasciitis including areas of reduess and edema shoud be peformed.

Also, surgical treatment by adequate debridement, drug therapy by antibiotics, and HBO therapy should be combined to treat necrotizing fasciitis.
\end{abstract}

Key words : necrotizing fasciitis (壊疽性筋膜炎), hyperbaric oxygen (HBO) therapy (高気 圧酸素治療）

\section{は じめに}

壊疽性筋膜炎 necrotizing fasciitis は, 細菌感染に

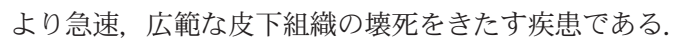
本疾患の発症はまれとされているが, 初期治療を適切
に行わないと敗血症, ショックなどの全身症状の増悪 をきたしやすく予後不良の疾患である. 本疾患は糖尿 病患者等の compromised hostに発症しやすく, 重 篤となることが多い。最近われわれは糖尿病に合併し た壊疽性筋膜炎の 1 例を経験したので報告する. 
症

例

患者 : 55 歳女性

主訴：左第 3 指痛, 腫脹, 発熱である.

現病歴：2004 年 7 月 1 日明らかな外傷はなく左 3 指基部の腫脹が出現， 7 月 3 日より同部位の発赤と腫 脹が増強し近医受診, 抗菌薬による加療を行うが症状 改善せず， 7 月 7 日より皮膚壊死症状を認め, 7 月 8 日紹介入院となる.

既往歴：糖尿病で 45 歳時に発症，現在インシュリ ン加療中である.

入院時全身所見 : 体温 $38.5^{\circ} \mathrm{C}$, 悪寒・戦慄強かつ たが血圧, 心拍数, 呼吸状態等のバイタル所見又はバ イタル徵候は安定していた.

入院時局所所見: 左中指の疼痛, 腫脹, 発赤が著し く, 指尖部を残し MP 関節より末梢における水疮形 成と壊死及び，また手背部に浮腫と発赤を認めた（図 1).

入院時検査所見：血液検査にて CRP 15.1, 白血球 数 11500 と炎症が高值であった. 空腹時血糖 $186 \mathrm{mg} /$ dl, Hba1c 6.5, であり糖尿病のコントロールは悪く, RBC 310 万 $/ \mathrm{mm}^{3}, \mathrm{Hb} 6.5 \mathrm{~g} / \mathrm{dl}$, Hct $22.2 \%$, と小 球性低色素性貧血を認めた。

入院時単純 $\mathrm{X}$ 線：軟部撮影にて右中指の著明な腫 脹を認めたが，ガス像は認められなかった（図 2).

\section{治 療 経 過}

7 月 8 日より, カルバペネム系抗菌薬 (MEPM) の点滴, 及び高気圧酸素治療開始の併用（以下, HBO）を開始したが，壊死の急速な進行を認め，7 月 9 日に MP 関節部より末梢の左第 3 指切断術およ び手背部の壊死組織除去術（以下デブリードメント） を行った（図 3 ).

7 月 9 日術中所見 : 左中指の広範な壊死亡, 皮下組 織に膿汁を認め, 筋, および腱組織を除いた軟部組織 は変性, 壊死が認められた. 手掌の壊死部分を切開する と濃汁の流出を認め, MP 関節部で第 3 指の切断を行 い皮膚の壊死組織を切除した。 また切断指を縦割する と内部から濃性の流出物あり, 腱を除いた軟部組織は 変性・壊死が認められた。また手背部は浮腫と発赤を 認めた.

抗菌薬の継続投与及び $\mathrm{HBO}$ 加療を行い, 術後 2,3

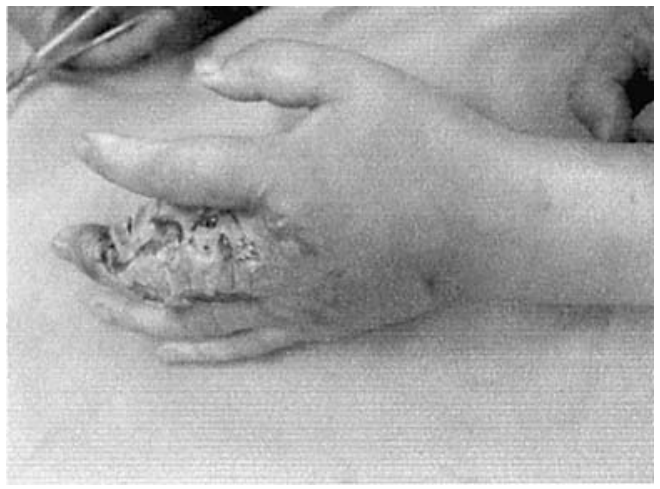

図 1 入院時時所見: 第 3 指は指尖部を残し, 紫斑, 壊死を認め, また手背部に浮腫と発赤を認める.
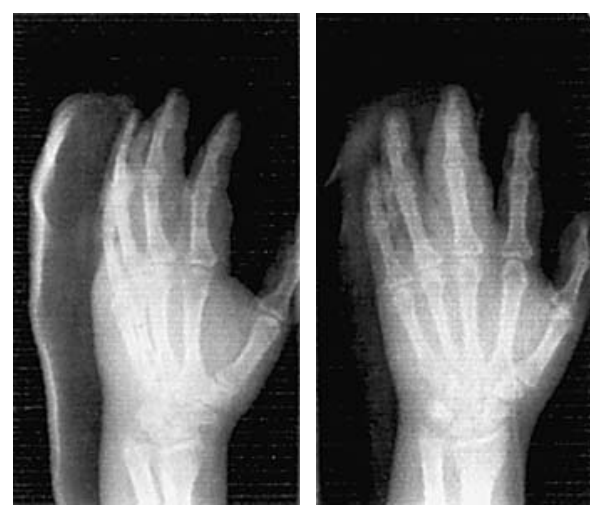

図 2 入院時単純 X 線像 軟部撮影にて右中指の著明な腫脹を認める. ガ 又像は認められず。

日は創壊死の進行はなかったが, その後，急速に壊死 の拡大を認め, 7 月 13 日浮腫部分を含めた手背部の広 範囲デブリードメントの追加手術を行つた（図 4).

7 月 13 日術中所見：壊死組織様と思われる部分か ら更に近位側で手背側から手掌側にかけ壊死組織切除 を行つた。切除した皮下組織より膿汁を認めた。壊死 組織は筋層には及んでいなかった。それまでの期間, 細菌培養では菌は検出されなかった（図 5).

経過によりカルバペネム系抗菌薬（MEPM）によ る効果が少ないと判断されたため合成ペニシリン (PIPC) 及びリンコマイシン系抗菌薬（INN）の投薬 に変更し, $\mathrm{HBO}$ 加療を継続した. 以降, 症状は改善 し, CRP : 1.82, 白血球数 : 5300 まで低下して, 炎 

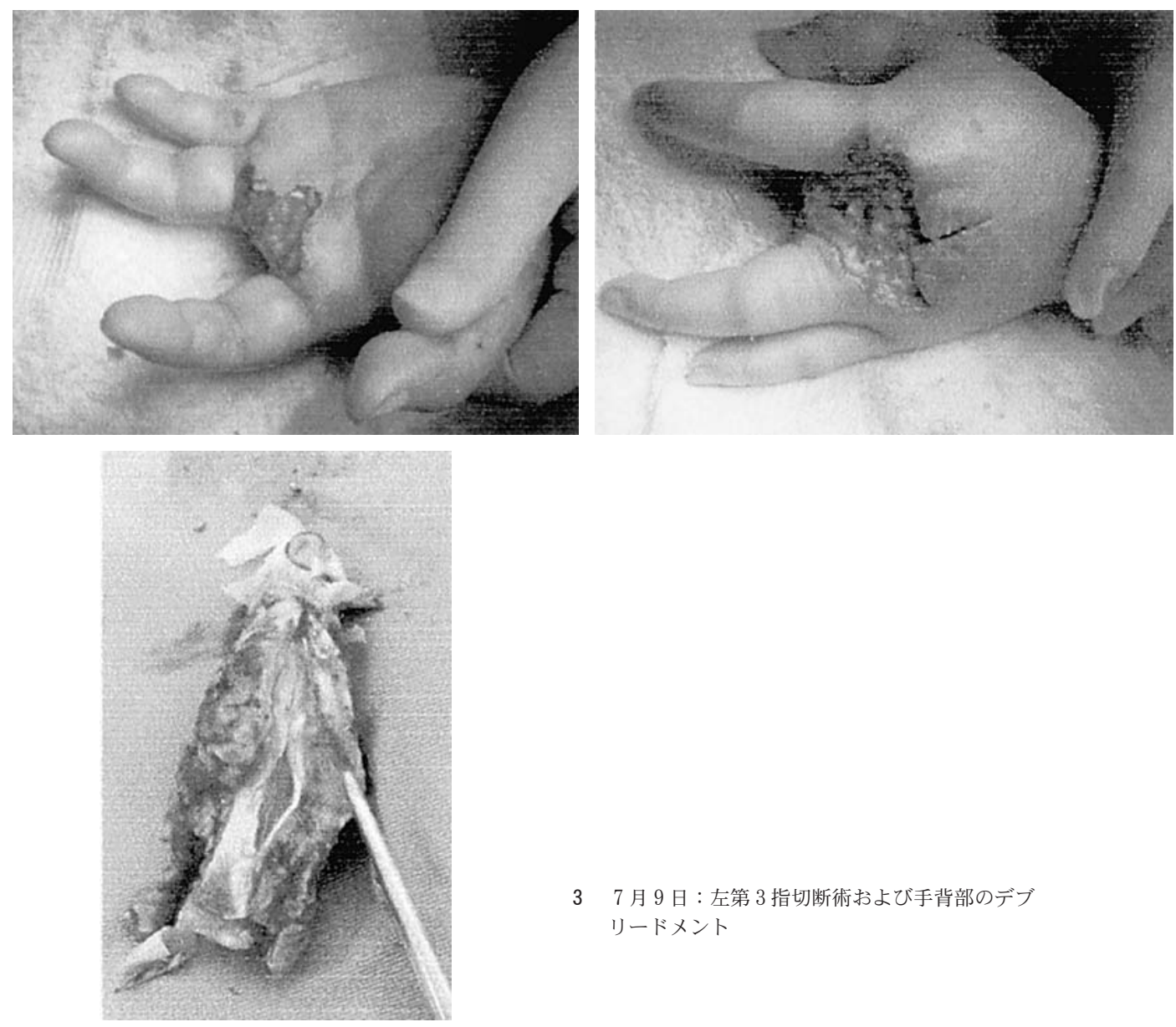

図 37 月 9 日：左第 3 指切断術および手背部のデブ リードメント
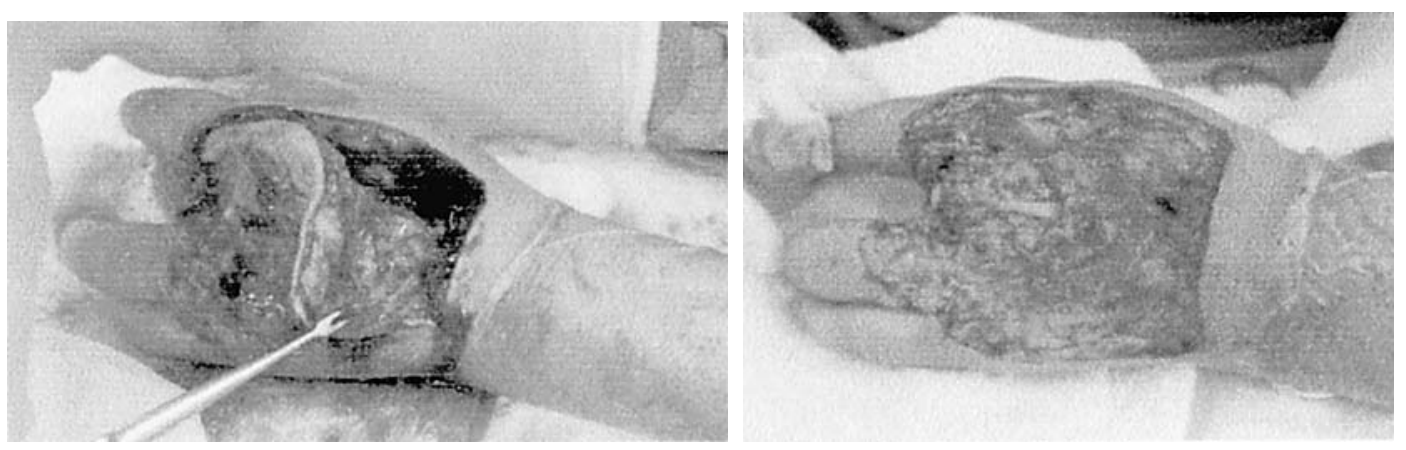

図47月 13 日：広範囲デブリードメントの追加手術後

症状態が改善してきたため, 7 月 18 日滅菌凍結乾燥 豚皮で被覆，以降，創壊死の進行は認められず，創の
肉芽も徐々に形成され，8月 20 日に遊離植皮術を行 い，生着も良好であった（表 1 ). 


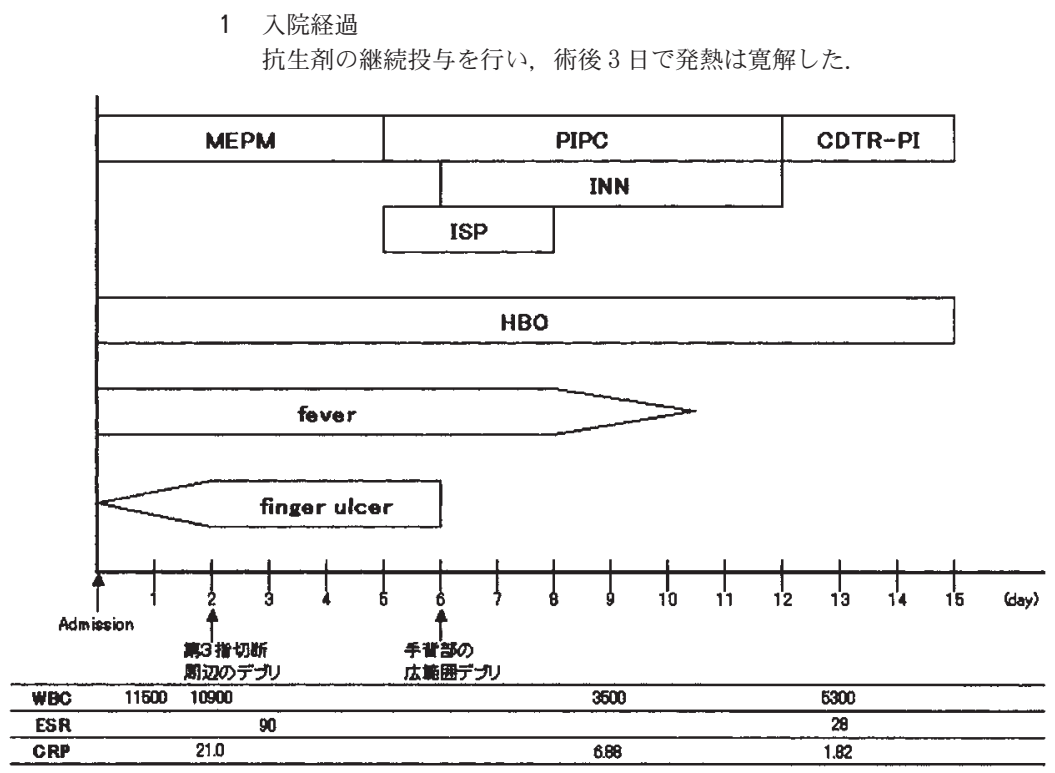

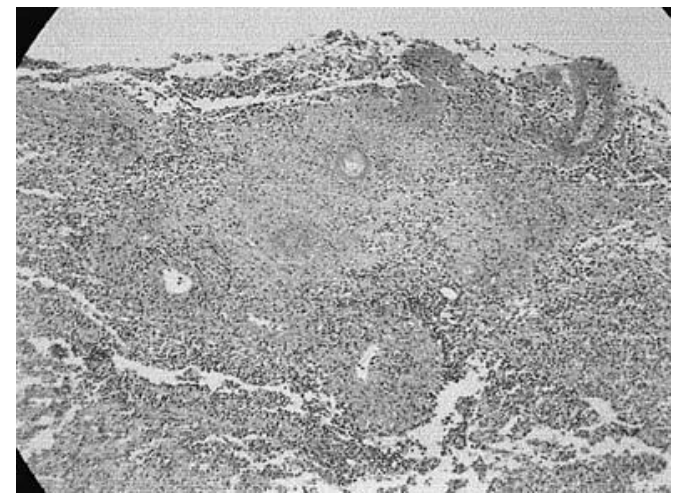

図 5 病理組織学的所見

左中指の切断指 : 表皮は欠如しており，真皮及 び皮下組織には, 壊死組織, 大膿瘍, 滲出及び 急性活動性の炎症細胞の集束が見られた.

\section{病 理 所見}

左中指の切断指の表皮は欠如しており, 潰瘍を呈し, 真皮及び皮下組織には，壊死組織，大膿瘍，滲出及び 急性活動性の炎症細胞の集束が見られた（図 5).
考察

壊疽性筋膜炎は外傷性のみならず，非外傷性の場合 もあり, 皮膚・皮下組織・筋膜に壊疽性病変をきたし 急速な経過を取って進行する予後不良の疾患である. 本症における予後不良因子としては, (1)治療開始まで の期間が 3 日以上のもの，(2)発症部位が近位に及ぶも の ${ }^{1)}$ (3)糖尿病, 肝疾患, 腎不全などの合併による compromised host の合併疾患のあるもの, の 3 つが あげられている ${ }^{2)}$. 浅原らは基礎疾患に糖尿病を有す る本疾患の死亡率は $50 \%$ で，有さない症例の死亡率 $21.6 \%$ に比し有意に高いと報告しており，糖尿病は 重症化の危険因子であるともいえる

自験例において発症部位は遠位発症例であるが，治 療までに 7 日が経過しており，しかも糖尿病のコント ロールが不良であつたため，難治例であることが考え られたが, 最小の切断で良好な治療経過を得ることが でき，デブリードメントと抗菌剤投与のみならず， $\mathrm{HBO}$ を併用した 3 者併用療法の効果であると推察さ れた。

$\mathrm{HBO}$ は大別すると，菌の静菌，殺菌作用，および 組織修復促進作用 2 つの作用が考えられており，白血 球の貧食作用や酸素殺菌能を高めて嫌気性菌のみなら 
ず，好気性菌に対しても静菌，殺菌的にはたらくとい われている. また，組織の酸素分圧を上昇させ，局所 の acidosis を改善し，末梢血管を収縮させ浮腫の軽 減に働き，また感染をともなった壊死に対して局所の 虚血を改善し良性肉芽を形成させることが報告されて いる4.

また死亡率と, HBO の関係についてであるが, $\mathrm{HBO}$ を行つた場合とそうでない場合の死亡率を比較 すると Mader J (1988） らの報告では，非 HBO 群 67\%, HBO 群 25\%, Riseman Jaet al (1988) らの 報告では非 $\mathrm{HBO}$ 群 $66 \%$ ，HBO 群 $23 \%$ との報告が あり明らかに死亡率の低下が認められていると思われ $る^{566)}$.

今回は, 初回のデブリードメント後 4 日で病変の進 行を認め, 再度デブリードメントの手術を行った.こ れは切除を極力回避する目的でかつ HBO の効果を期 待したうえでの治療方針であった. しかし結果として 壊瘟性筋膜炎のデブリードメントは発赤, 浮腫の部分 を含め広範囲に行う必要があるものと思われた.

壊疽性筋膜炎の治療については早期の診断と，早期 のデブリードメントと早期の抗菌薬投与及び全身管理 が原則であることは論を待たないが，棚橋らは壊疽性 筋膜炎は経過に多様性が認められ, 急性型と亜急性型 があるとの報告している，急性型は症状が急速に進行 して, 広範な壊死を生じ全身状態がおかされるタイプ であるといわれており, 亜急性型は数週から数ヶ月の 経過で壊死性の皮膚が脱落し, 潰瘍を残すが, 生命予後 の良いタイプであるといわれ,一般に急性型のタイプ が強調されるが, 亜急性型の症例も多く報告されてい る7. 当院では過去に急性型, 亜急性型どちらもの壊疽 性筋膜炎の報告を行ってきたが，そのどちらもが $\mathrm{HBO}$ は明らかな死亡率の低下を認め, 治療の有効が 高いものと考えている ${ }^{899}$.
壊疽性筋膜炎に対しては適切なデブリードメントに よる外科的療法，抗菌剂による薬剤療法，と $\mathrm{HBO}$ を 併用した 3 者併用療法が必要であると思われた。

結語

(1)比較的まれな壊疽性筋膜炎の診断にて右第 3 指切 断術，およびデブリードメントを行った一症例を経験 した.

(2)壊疽性筋膜炎に対しては適切なデブリードメント による外科的療法, 抗菌剤による薬剤療法, および $\mathrm{HBO}$ を併用した 3 者併用療法が必要であると思われ た.

\section{参 考 文 献}

1）浅原洋資ほか：壞死性筋膜炎の 6 例。整外と災外， 52 (2) : 336-340, 2003.

2）川嶌眞人はか：化膿性骨䯣炎．整形外科，55(8)：927933, 2004.

3）川嶌眞人ほか：壊疽性軟部組織感染症に対する高気圧 酸素治療。日高圧医誌，24(4)：217-226, 1989.

4) Mader, J. T.: Problem wounds: the role of oxyegen. Mixed anaerobics of aerobic soft tissue infections, 173-186. Davis, J. C., Hunt, T. K., New York, Elsevier, 1988.

5) Riseman, J. A., Zamboni, W. A., Curtis, A., et al.: Hyperbaric oxygen therapy for necrotizing fasciitis reduces mortality and the need for debridements. Surgery, $108: 847-850,1990$.

6）重田哲哉：刺創に生じた A 群連鎖球菌による手指壊死 性筋膜炎の 1 例。整形外科, $53(10) ： 1324-1325,2002$.

7）棚橋朋子ほか：Necrotizing Fasciitis. 西日本皮膚科, $52(3): 449-456,1990$

8）土田芳彦：集中治療を要する整形外科感染症一破傷風, 壊死性軟部組織感染症一. 日整会誌, $78: 400-410,2004$.

9）内田和宏ほか：軟部組織感染症に対する高圧酸素療法 の小経験。整外と災外，35(2)：485-487，1986. 